\title{
Study on Current Situation and Comprehensive Evaluation of Green Plant Community
}

\author{
Khalmuratov Polat \\ Karakalpakstan State University named after Berdakh, Nukus, Uzbekistan
}

\begin{abstract}
The article describes the current state of the vegetation of the Nurymtubekskiy tugai territory. The studies were carried out on the territory of the Nurymtubekskiy tugai. For tugai phytocenoses, 5 species of woody plants are characteristic. Of the herbaceous plants, 85 species were noted. Meadow vegetation is represented by perennial herbaceous mesophytes.
\end{abstract}

Keywords: Phytocenosis, riparian vegetation, halophilic vegetation

\section{Introduction}

Biodiversity conservation, inventory of biological objects, study of rare and endangered species are currently of great importance. Tugai vegetation is one of the most widespread in Karakalpakstan and the most convenient object of botanical research. The study of tugai vegetation is of great importance for assessing the transformation of natural landscapes under the influence of anthropogenic and natural factors and has a huge array of primary information for further analysis.

In Uzbekistan, the determination of the composition of natural flora on the basis of modern research methods, assessment of the state of vegetation cover, conservation and sustainable use occupy a special place among the priority areas of biodiversity conservation. At this stage of phytocenotic research and the accumulation of new data, it is important to introduce systemic research in order to preserve biodiversity.

Nurymtubek tugai and its coastal territories are distinguished by the originality of their phytocenotic composition. It must be emphasized that the study of the composition of phytocenoses located in the northern regions is of great importance in understanding the phytocenoses of tugai throughout the territory of Karakalpakia.

In the Nurymtubek tugai, halophilic vegetation is found both in solid massifs and in separate spots among saline soils of different types of deserts. Naturally, the described vegetation often comes into contact with other types of vegetation tugai, psammophilic, ephemeral; therefore, many transitional halophytic communities are observed in nature. The vegetation of saline habitats is characterized by heterogeneity and spotting. A complex combination of plant communities is often observed even in a small area. Such variegation of the vegetation cover under these conditions is due to a number of reasons. It occurs with barely noticeable changes in the microrelief, leading to an uneven distribution of salts and changes in moisture conditions, as well as under the influence of the plants themselves. So, a significant change in the upper layer of the soil occurs under the influence of litter of annual shoots of species of the genus comb, black saxaul. In addition, readily soluble salts have high mobility, they are easily redistributed, migrate and during the season are washed in to a certain depth - in the spring under the influence of precipitation, and are pulled to the surface with high evaporation - in the summer. All these factors are reflected in the distribution of vegetation. The reasons for the emergence of the complexity and mosaic nature of vegetation are covered in detail in many. Halophytes are considered as a special type of xerophytes. They are resistant to high temperatures $[1,2,3]$.

In 2015-2016. we carried out route-reconnaissance studies of the current state of biodiversity in the territory of the Nurymtubek Tugai. The main plant communities, their species composition, abundance, vitality of the main plant species and the coordinates of the studied areas were studied. Representatives of the family Chenopodiaceae, such as Haloxylon aphyllum, Halostachys belangeriana, Halocnemum strobilaceum, species of the genus Kalidium, Salicornia herbacea, species of the genera Climacopte as well as from salt-producing plants, species of the genera Tamarix, Reamuria, Halolachne, Limonium, Frankenia, Gressa, Aeluropus, etc.

The following families have been identified: Typhaceae, Poaceae, Salicaceae, Chenopodiaceae, Caryophyllaceae, Ranunculaceae, Fabaceae, Zygophyllaceae, Tamaricaceae, Elaeagnaceae, Gentianaceae, Apocynaceae, Asclepiadaceae, Convolvulaceae, Solraceae and others.

Representatives of the Chenopodiaceae family rank first in terms of the number of species and play an important role in the composition of the vegetation cover. This is due to the presence of large areas of saline lands.

The vegetation cover of the Nurymtubek tugai territory is determined by tugai, meadow, halophilic, psammophilic vegetation. The tugai phytocenoses are characterized by a small number of species. Aryan poplar - Populus ariana dominates in arboreal tugai. Dode, Turkmen sucker Elaeagnus turcomanica N. Kozl. The most typical shrubs are: multi-branched comb - Tamarix ramosissima Ledeb., Bristly-haired city - Tamarix hispida Willd., Loose city Tamarix laxa Willd., Five-lobed city - Tamarix pentandra Pall.)Voss. Of the herbaceous plants, 85 species were noted. The most widespread are: rough kendyr - Trachomitum scabrum (Bed. Et Bell.) Pobed., Common licorice Glycyrrhiza glabra L., false yantak - Alhagi pseudalhagi (Bieb.) Desv., Common reed - Pragmites australis (Cav.) Ex Stend., Caspian Karelinia - Karelinia caspia (Pall.) Less, 
Amudarya green leaf - Zigophyllum oxianum Boriss, creeping mustard - Acroptilon repens (L.) DC., Fragile wheatgrass - Agropyron fragile (Roth) Nevski, Atriplex cana $C A$ - Mey. in Lebed, swing the pierced - Gypsophiia perfoliata L., the Aral climacopter - the salt marsh coastal Aeluropus litoralis (Gouan) Parl, the field bindweed Convolvulvus arvensis lanopaus. Caspian saltwort Halostachus caspica (Bieb.) CA Mey, etc. Meadow vegetation is represented by phytocenoses of herbaceous perennial mesophytes Glycyrrhiza glabra L, Alhagi pseudalhagi (Bieb.) Desv, Pragmites austabralis (Cavit. (Bed. Et.Bell.) Pobed, et al. Formerly widespread communities of southern reed in the process of desertification were replaced by communities of sinners and climate copters of the Aral and woolly climate copters. Mainly edificators and subedificators are floodplain and salt tolerant plants; Populus ariana Dode, Elagnus turkmanica N. Kozl, Tamarix pentandra Pall, Tamarix ramosissima Ledeb, Tamarix leptosthahus Bunge, Halimodendron halodendron (Pall) Boss, Glycycyrrhyza glabra L, Apconum scrabrum Celuba communisan, Pragmitis communal litoralis (Goan) Parl, Clematis orientalis L, Karelinia caspica (Pall.) Less, Alhagi pseudoalhagi (Bieb.). The rest of the species are rare or single, without affecting the course of successional changes and the structure of the phytocenosis, such as Lycium rutheum Murr, Limonium otolepis (Shrenk.) Kuntze, Capparis spinosa L, Haplophyllum bunge Trautv,Acroptilon repens (L.) DC, Typha laxmanii Lepech, Cynanchum sibiricumWild, Sphaerophysa salsula (Pall.) DC, Dodartia orientalis L, etc. The minor components include species that weed in crops or fallows, where they often dominate, for example, such as Calamagrostis dubia Bunge, Suaeda altissima (L) Pall, Suaeda linifolia Pall, Suaeda salsa (L) Pall, Chenapodium album L, Polygonum aviculare L.

Where the soils are not saline, the vegetation cover characterized by high density is dominated by mesophytic floodplain-tolerant plants with adaptive properties to flooding, such as Populus ariana Dode, Glycycyrrhyza glabra L, Halimodendron halodendron (Pall) Boss.

Where the soils are saline, a different ratio of edificators, coedificators and related species is observed in the grass cover. Some of the moisture-loving floodplain grasses fall out, the other part loses the degree of abundance and, conversely, the role of salt-tolerant plants increases markedly, i.e. hygrophilous salt-tolerant plants develop strongly: for example Halostachus belangeriana (Mod), Zygophyllum oxianum Boriss, Aeluropus litoralis (Goan) Parl, Limonium otolepis (Shrenk.) Kuntze, Suaeda altissima $L$. From the group of herbaceous tugai phytocenoses, only some associations of yantak are preserved, occupying large areas.

The change in the vegetation cover under conditions of aridization of the environment of the studied region is associated with climate change and the cessation of flood floods, deterioration of water nutrition of plants, drying out and salinization of soils, increased direct anthropogenic loads: felling, trampling, grazing, mowing, which created conditions for the replacement of hydrophilic communities by xerophytic and haloxerophilic [4].

\section{Conclusion}

Thus, we have established the current state of the vegetation of the territory of the Nurymtubek tugai, collected information on the quantitative composition, distribution area. To preserve the plant gene pool, we propose the creation of protected areas, which will facilitate the identification of rare and endangered plant species and ensure the biodiversity of the region under study and the protection of this territory.

\section{Output}

We carried out studies of the primary inventory of plants only for one year (2017). Therefore, in order to obtain reliable and sufficient information about the current state of biodiversity of the plant world, it is necessary to maintain an inventory of regional plant species of the territory of the Nurymtubek tugai for several years. Data on the state of herbaceous, shrub, and woody vegetation of the Nurymtubek tugai, spatial distribution of the main species, degradation of grass and soil cover, disturbance of ecosystems are of great importance in conducting a permanent inventory of the diversity of this tugai massif

\section{References}

[1] Akzhigitova N.I. Halophytic vegetation of Central Asia and its indicative properties. 1982.

[2] Bakhiev A.B. Plant indicators of soil and groundwater salinity in the Amu Darya delta. Publishing house. "FAN", Tashkent, 1979.

[3] Bakhiev A.B. Ecology and change of plant communities in the lower reaches of the Amu Darya. Publishing house. "FAN". Tashkent, $1985.192 \mathrm{p}$.

[4] Treshkin S.V. Influence of changes in ecological conditions on the dynamics of riparian communities in the Amu Darya delta. KOANRK Bulletin, 1996, No. 1. 